UDC 31:630:001.8(477)

JEL Classification: C81, Q23

Doi: 10.31767/su.2-3(89-90)2020.02-03.02

\author{
T. V. Kobylynska, \\ DSc in Economics, \\ Deputy Head, \\ Main Department of Statistics in Zhytomyr region, \\ E-mail: TVstat@i.ua \\ ResearcherID: N-2678-2018, \\ ORCID: https://orcid.org/0000-0001-8376-9656; \\ N. Yu. Huseva, \\ Head of the Department, \\ The State Statistics Services of Ukraine, \\ E-mail: N.Guseva@ukrstat.gov.ua \\ ORCID: https://orcid.org/0000-0002-2655-6272
}

\title{
A Statistical Study of the Forestry in Ukraine
}

The article is devoted to the analysis of the forestry in Ukraine as the reference point for further development of the framework for constructing the national forest account allowing for a description of interactions between economic activities and forests as a nature environment, and for consistent and comprehensive integration of environmental and economic problems in this field. The study covers the existing statistical definitions, classifications and the available statistical information about the forest, selected forestry indicators for Ukraine, the existing sources of data for the analysis of forestry, with proposing the necessary steps for further applications of forest accounting tools, in order to construct the forest account.

It is pointed out that the forestry is represented by two large groups of institutional units: physical persons or groups of physical persons in form of households; legal entities, established and operated in keeping with the law, irrespective of what persons or entities may be their owners or managers. The main categories of legal entities are corporations, non-commercial organizations, and public administration bodies.

It is determined that the main sources of data about the forest fund and forest resources of Ukraine are as follows: (i) statistical information based on the data from enterprises, obtained from official statistical observations of the State Statistics Service of Ukraine; (ii) administrative data based on the data from enterprises, obtained by public administration bodies (The State Service of Ukraine on Geodesy, Cartography and Cadastre, the State Agency of Forest Resources of Ukraine, the State Custom Service, the State Taxation Service) as part of functional responsibilities; (iii) the data of the national inventory of forests, obtained by the authorized bodies. The latest official data of the national forest inventory for Ukraine are available as of January 01, 2011, but these data have not been published yet in a proper manner.

It is demonstrated that the official statistics cover a limited set of statistical data about the forestry due to the institutional constraints. A dynamic and structural analysis of the forest lands is explored, with outlining the main problems related with improving methodological approaches to the formation of the forestry statistics. The analysis allowed for determining the main areas of improvements in the forestry accounting and coming up with propositions of necessary steps to solve the problems of statistical studies of this industry.

Key words: forestry, forest areas, forest and other forest lands, wood, operational roundwood, fuel wood, statistical study.

Importance of the research theme. Ukraine is a country with one of the largest forest areas in Europe and with old traditions of forestry. Due to their diverse structure and intensive natural rehabilitation, forests are a category of resources that are the key to the future development of this country. Ukraine, like all other countries of Europe with rich forests, faces tremendous challenges related with preparation of forests to future climate change, on the one hand, and has specific problems of the developing forestry and wood industry in a sustainable and efficient way. In the era of limited resources, wood is becoming a raw material of primary importance. Logging and sales of roundwood, i. e. operational and fuel wood, allows for stable profits. However, when raw wood is processed, its price can be increased several fold and become a main source for the rapid development of the domestic wood industry and the alternative energy generation.

The Association Agreement signed by EU and Ukraine in 2014 opened up a new phase in the development of contract relations between EU and Ukraine, aimed at the political association and economic integration. The association offers a step forward on the way to EU accession. According to Article 355 of

(C) T. V. Kobylynska, N. Yu. Huseva, 2020 
the Association Agreement, to be harmonized with European norms and standards, the national statistical system has to rely upon fundamental principles of UN on the official statistics with consideration to acquis EU in the statistics field, the European Statistics Code of Practice in particular [1]. Acquis in the statistics field are set forth in the annually updated compendium of statistical requirements, considered by the Parties as Annex XXIX to the Agreement. The latest available version of this compendium can be found on the website of the Statistical Office of the EU (Eurostat) [2].

The description of the section 3.1.1 "Forest Statistics and Accounts" of the above mentioned compendium shows that the countries of EU and the European Free Trade Association supply annual data on the output and trade of wood and wood products on the basis of the Joint Forest Sector Questionnaire (JFSQ) [3], which provides the guidelines for the European Economic Commission, UN, the Food and Agricultural Organization, Eurostat and the International Tropical Timber Organization (ITTO) at the global scale. The economic data on forestry and logging is collected by use of other questionnaire: the European Forest Accounts as part of the Integrated Environmental and Economic Accounting of Forests (IEEAF) [4].

A review of the current forest law in EU shows that Ukraine needs to expand considerably its regulatory effort in harmonization of the law, to meet the requirements of regulatory acts of $\mathrm{EU}$ in all the thematic areas of the new EU Forest Strategy [5]. At the same time, the nomenclature of measures on adaptation of the environmental and forest statistics related with the forestry, which is fixed by the Association Agreement, is a necessary set of urgent actions to achieve the conformity of the national forestry law with the respective EU framework. Hence, to have the provisions of the Agreement implemented, Ukraine needs to meet, as soon as possible, the requirements for collection and aggregation of the data on the Ukrainian wood exports in keeping with European questionnaires, and to use European approaches to the forest accounting.

Forestry practices in Ukraine are based on principles and methods established 30-40 years ago or even earlier. Given the cardinal change in the external conditions (political system, policy, economy, and climate) and the emergence of new knowledge and technologies, a large part of the existing ones have become obsolete and hindered the development. The traditional conservatism of the forestry industry and the lack of necessary competencies with persons responsible for decision-making make the forestry unattractive for new approaches in all the functional areas. A statistical study of the forestry in Ukraine will be conducive for dissemination of knowledge about the European assessment in the field, and will help systematize the data required for constructing the forest account of Ukraine.
Literature review. As nature systems, forests are located on the crossroad of many environmental and economic problems, including climate change, loss of biodiversity, erosion of soils, water stress or stability of highland areas. The products that can be derived from forests are quire diverse and capable to meet a wide range of needs, including food, industry, dwelling and energy, but the assessment of the forestry impact on the economic development requires an appropriate statistical base. At the same time, the forest sector of Ukraine, which covers forestry, sawmill, pulp \& paper industry and bio-energy, still remains inadequately explored due to a number of problems caused by the lack of complete and reliable official statistical information on forests and forestry performance.

The issues of forestry, forestry studies, forest planting and forest cultivation, forest melioration, monitoring in this field, radiology, selection of wood species etc. have been investigated by Ukrainian researchers such as I. Buksha, M. Hordiienko, V. Krasnov, O. Mihunova, V. Pasternak and others. Methodological, organizational and practical aspects of the development and formation of the environmental statistics components have been dealt with by V. Danylko, A. Yerina, O. Osaulenko, N. Parfentseva and others. However, a large part of issues concerned with the integrated environmental and economic accounting of forests and its development prospects in Ukraine have been out of focus and call for further elaboration, especially through the prism of the statistical monitoring of these processes. Studies attempting to find solutions for these issues are becoming very significant for the current official statistics of Ukraine and the overall development of statistical science and practice, because they largely determine the quality of information support for management at each level.

The article's objective is to conduct monitoring of the main forestry indicators in Ukraine, to outline the problems of accounting and statistical studies of forests, and to find their solutions.

Results. The organizing structure of the subsection "Forestry" is a difficult issue. Currently, the normative and legal regulation of the forestry is subject to the responsibility of the Ministry for Protection of Environment and Natural Resources of Ukraine. The relations concerned with the forestry involve public administrative bodies and local self-government bodies, legal entities and citizens [6]. The economic competence of public administration bodies and local self-government bodies is implemented by respective public or communal departments (legal entities) [7].

The forestry is represented by two large groups of institutional units: physical persons or groupi of physical persons in form of households; legal entities, established and operated in keeping with the law, irrespective of what persons or entities may be their owners or managers. The main categories of legal entities are 
corporations, non-commercial organizations, and public administration bodies.

More than $90 \%$ of legal entities engaged in the forestry belong to the sector of corporations, including non-financial corporations, created specifically for the commercial production of goods and services that are sources of income or other financial benefit for their owners. A part of legal entities engaged in the forestry belong to the general government that includes ministries, public services, agencies, inspections, public committees, public administration bodies with special status, regional or local public administration bodies. The Classification of Institutional Sectors of the Economy states: "The main distinction between legal entities of corporations and public administration bodies stems from the distinctions in the objectives for which the production is performed. Corporations make products for the market and seek to sell them on economically significant (market) prices. Public administration bodies organize and finance the supply of goods and services to selected households and to the community on the whole, and they incur costs on the final consumption. The products made in this sector are usually provided either free of charge or on the prices that are set on the basis of decisions not related with market mechanisms. The activities of non-commercial organizations are aimed at the achievement of economic, social or other results in the field of forestry, without the receipt of profit to be further distributed between the parties involved" [8].

The main sources of data on the forest fund and forest resources of Ukraine as follows:

1) statistical information based on the data from enterprises, obtained from official statistical observations of the State Statistics Service of Ukraine;

2) administrative data based on the data from enterprises, obtained by public administration bodies (The State Service of Ukraine on Geodesy, Cartography and Cadastre, the State Agency of Forest Resources of Ukraine, the State Custom Service, the State Taxation Service) as part of the functional responsibilities;

3 ) the data of the national inventory of forests, obtained by the authorized bodies. The latest official data of the national inventory of forests for Ukraine are available as of January 01, 2011, but these data have not been published yet in a proper manner.

The forest statistics of Ukraine is formed on the basis of the above mentioned data sources. The resulting information can be used for analyses and further computations, as well as in publications of public administration bodies and local self-government bodies, by business circles (institutions, enterprises, organizations), scientists and researchers, mass media, citizens and international organizations, such as the United Nations Food and Agricultural Organization (FAO), which website displays the global assessment of forest resources of various countries, including Ukraine, for the year of 2015 .
The share of forests and other forest lands in Ukraine range from 15 to $18 \%$ of the total country area. In average, each country resident accounts for 0.2 hectares of forest and other forest lands. According to the State Statistics Service of Ukraine, large business entities cannot be found in the forestry of Ukraine. Nearly $80 \%$ of the staff is employed in medium-sized business entities, and the rest work in small businesses. The employment in the forestry businesses fell by nearly $9 \%$ in 2018 compared with 2010, making 65.5 thousand persons. The overwhelming majority of employees in the forestry (more than 70\%) are engaged in logging. However, the sales of goods and services by business entities in the forestry increased in 2018 by nearly four times compared with 2010, amounting to 22.6 billion UAH [9].

Capital investment in the forestry and logging in Ukraine grew up from 177.8 to 980.3 million UAH in 2010-2018 (Figure 1, constructed by data from [10]). Unfortunately, the capital investment fell down to 548.7 million UAH in 2019. Meanwhile, more than $80 \%$ of the capital investment in the forestry and logging come from internal funds of business enterprises and organizations. The share of capital investment in the forestry of Ukraine is minor, making $0.1 \%$ of the total capital investment.

A core indicator of the sustainable development of forests across the world and the main parameter of the maintenance of forest lands is the forest area. It is designed to reflect the positive and negative change, to identify the areas of deforestation and to revise the regional patterns of change.

According to Article 13 of the Constitution of Ukraine, land, its bowels, air, water and other natural resources located within the boundaries of the Ukraine's territory, natural resources of its continental shelf and exclusive (marine) economic zone are subject to the ownership right of the Ukrainian people [11]. The forests of Ukraine can be in public, communal or private property.

According to international definitions, the main distinguishing line is drawn between the forests that are in public and private property. For data consistency at the international level, the forest area and forest lands in Ukraine are divided into two groups by ownership form: those in public (including communal) property and those in private property. While the right of public (including communal) property for the forests can be gained and implemented by the government without limitations on their area, limitations on private forests are not applied only for degraded or unproductive lands, whereas the forests created as part of rural households, farms or other entities have the upper margin of 5 hectares. In times of socialism, the private property on forests was ignored by national forest policy leaders. Compared with rather intensive management of public forests, private forests were neglected by forest policy managers and private owners. Given that the private 


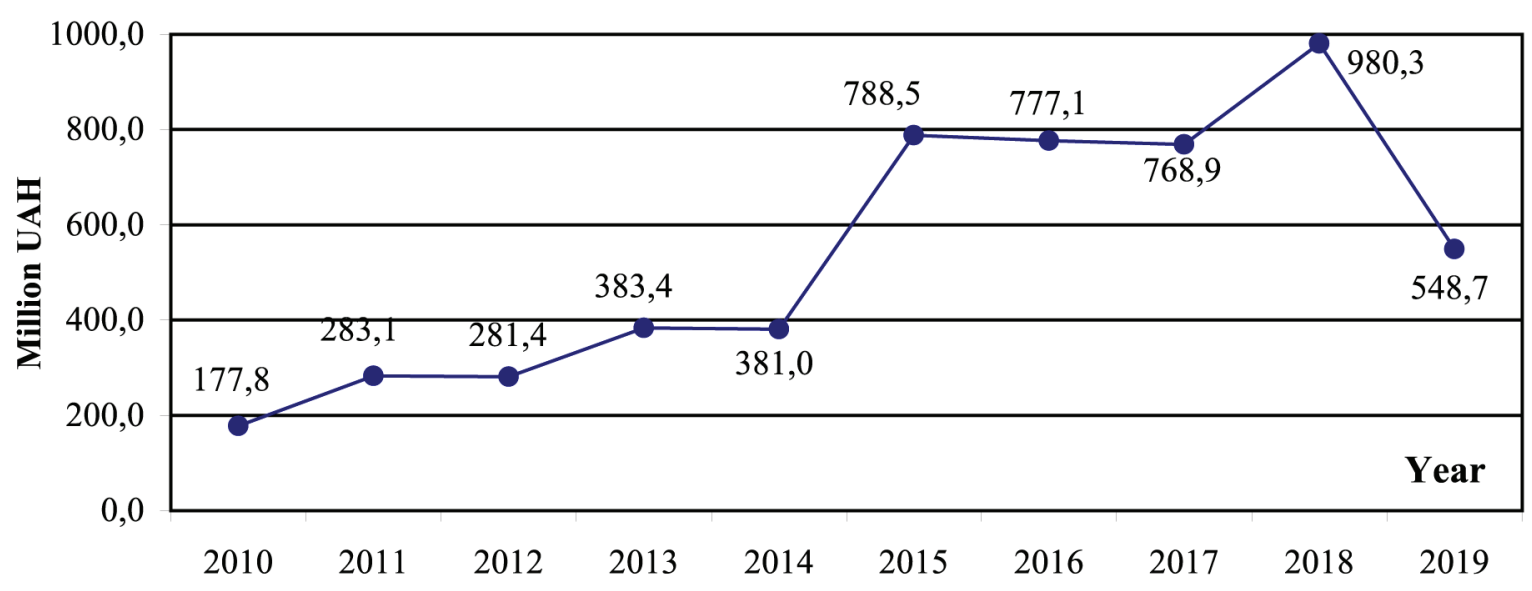

Figure 1. The capital investment in the forestry and logging in Ukraine

owners in Ukraine are not organized in professional associations and their property is small-scaled and scattered, the current forest policy of Ukraine is set up on the assumption of small contributions of private owners of the forests or by ignoring them at all. The official number of private owners of forests in Ukraine is not known, which can be explained by several reasons. The data of land books and cadastres are not entirely accurate, as a part of information was destroyed in time of extreme circumstances. Forest lands are for the most part subject to family inheritance, but in many cases the procedure for formal transfer of the property right is not officially complete. Much more often, land cannot be appropriated by individual physical persons, because the procedure of land division is quite expensive and labor-consuming, whereas potential benefits of one owner from his inherited part of the land tend to be lower than the costs. Therefore, in many cases a forest asset is owned by a group of people (usually members of one family) on the shared basis, who know the local boundaries and use the land mostly sporadically and for own needs. The fuel wood for household needs is a prevailing end use of private forests, and only $20 \%$ of private owners are focused on the market, selling either firewood or wooden boards.
According to the data of the State Agency on Forest Resources of Ukraine, the share of forests in private ownership is smaller than $0.1 \%$ of the total forest area, the rest being public (including communal) forests [12]. However, the share of private forests has been slightly increasing over the latest 20 years. It is caused by far and large by the overall tendency of spontaneous afforestation in the abandoned agricultural lands in rural areas.

In the Central Framework of the EnvironmentalEconomic Accounting, adopted by the United Nations Statistical Commission in 2012 as an international statistical standard, forests are considered as a form of land cover, with the forestry representing a category of land use [13].

According to Append 3 to the Procedure for maintenance the State Land Cadastre, approved by the Decree of the Cabinet of Ministers of Ukraine from 17.10.2012 No 1051 «Approval of the Procedure for the State Land Cadastre" (with amendments), agricultural purpose is one of the main purposes of lands recorded in the land cadastre, which are further subdivided by purpose, as shown in Table 1 and 2 (compiled by data from $[14 ; 15])$.

The classification of purposes of forestry lands in the State Land Cadastre

\begin{tabular}{|l|l|l|}
\hline \multicolumn{2}{|c|}{ Code } & \multicolumn{1}{|c|}{ Title } \\
\hline Section & Subsection & \\
\hline 09 & & $\begin{array}{l}\text { Forestry lands } \\
\text { These are the lands covered by forest plants and not covered by forest plants, non- } \\
\text { forest lands that are provided and used for forestry purposes, except for the lands } \\
\text { occupied by green forest plantations within the boundaries of settlements, which } \\
\text { are not included in the category of forests, as well as the lands occupied by separate } \\
\text { trees, groups of trees or bushes on agricultural plots, or on backyard, country cot- } \\
\text { tage and garden plots. }\end{array}$ \\
\hline & 09.01 & For forestry and related services \\
\hline & 09.02 & For other forestry purposes \\
\hline & 09.03 & $\begin{array}{l}\text { For the purposes mentioned in subsections 09.01-09.02, and for preservation and } \\
\text { use of lands of the nature reserve fund. }\end{array}$ \\
\hline
\end{tabular}


The nomenclature of lands classified as forest lands by the Classification of Lands of the State Land Cadastre

\begin{tabular}{|c|c|c|}
\hline \multicolumn{2}{|c|}{ Code } & \multirow{2}{*}{ Title of land } \\
\hline Group & Subgroup & \\
\hline 004 & 00 & $\begin{array}{l}\text { Shrub vegetation of natural origin } \\
\text { The group includes lands covered by thickets of perennial woody shrubs }\end{array}$ \\
\hline 005 & 00 & $\begin{array}{l}\text { Forests and other lands covered by forest } \\
\text { The group includes forest lands and other lands covered by forest whatever the } \\
\text { purpose of the lands on which they are located. The group does not include green } \\
\text { vegetations within the boundaries of settlements (parks, gardens, squares, boulevards } \\
\text { etc.), which are not formally classified as forests and other lands covered by forests; } \\
\text { farm buildings and yards, farm roads and skips on agricultural lands, marshes, waters, } \\
\text { as well as } \\
\text { agricultural lands located in such forests. }\end{array}$ \\
\hline 005 & 01 & $\begin{array}{l}\text { Forest lands covered by forest plants } \\
\text { The subgroup includes forest lands covered by wooden and shrub vegetation, with } \\
\text { the fullness of young plants } 0.4 \text { or more, in other age group } 0.3 \text { or more (i. e. tree } \\
\text { crowns occupy evenly at least } 40 \%(30 \%) \text { of the land area). }\end{array}$ \\
\hline 005 & 02 & $\begin{array}{l}\text { Forest lands not covered by forest plants } \\
\text { The subgroup includes forest lands not covered by forest plants constantly or } \\
\text { temporarily (due to the heterogeneity of natural forest complexes, forestry activities } \\
\text { or natural calamity etc.), such as the forest lands occupied by open forest plants, } \\
\text { forest hotbeds and plantations, as well as forest roads and clearings, forest fire } \\
\text { prevention gaps, forest drainage ditches and channels that are subject to } \\
\text { afforestation (conflagrations; plants that perished; felling, forest edges, open wood- } \\
\text { land etc.), departmental railways and automobile roads (of forestry companies), dirt } \\
\text { roads, trails, compartment lines, technological corridors, portages, clearings, plan- } \\
\text { tations, dendrology gardens; plantations, as well as greenhouses and glass-houses } \\
\text { intended for planting of harden material }\end{array}$ \\
\hline 005 & 04 & $\begin{array}{l}\text { Other areas covered by forest } \\
\text { The subgroup includes the lands covered by thickets of perennial woody shrubs on } \\
\text { agricultural lands, cottage lands of individuals with the fullness of plants equivalent } \\
\text { to the fullness specified in the subsection } 005.01 \text {, and not classified as forest lands. }\end{array}$ \\
\hline
\end{tabular}

In the international practice, the definition of forest lands as a classification category of land use is nearly fully harmonized between Eurostat, FAO, OECD, and UN ECE. Forests as part of forest lands are separated from other forest lands on the basis of various parameters, such as the percentage of tree crown, the minimal area etc. The forest is defined as a land with the coverage of tree crown more than $10 \%$ and the area larger than 0.5 hectares. Upon the maturity, the trees on the place of growing are expected to be able to achieve the minimal height of 5 meters. Other forest lands are defined as lands with 5 to $10 \%$ coverage of tree crown, capable to achieve the height of 5 meters on the place of growing upon maturity, or with more than $10 \%$ coverage of tree crown, not capable to achieve the height of 4 meters on the place of growing upon maturity (such as dwarf trees), as well as the zones with the coverage of shrubs or bushes on the area more than 0.5 hectares and with the width of more than 20 meters. The area of forests and other forest lands, as defined in the international forestry statistics, does not cover all the land with trees. It implies that some "land with trees" is to be excluded from the category of lands "forests and other forest lands" in the classification of land use. The areas with importance as recreation places for city residents (municipal parks or gardens) or as eco-systems (scattered trees etc.) need to be recorded in other categories of the land classifi- cation. For example, in France these areas account for about 5 to $10 \%$ of the total forest land [4].

The main source of data on forests are forest inventories, but because they do not use a similar methodology or margins at country level, cross-country comparisons or even confrontations of various statistical data for one country need to be made with great caution. Yet, international definitions need to be preserved as they offer a single ground for reconciliation of data at global level.

The purpose of statistical classification of forests and other forest lands is to integrate economic aspects of the forest accounting by the two main groupings:

- forests available for wood supply (operational): "forests and other forest lands where neither legal nor economic nor specific environmental limitations can have essential impact on wood supply. This group includes the areas with no logging, in spite of the absence of the above limitations, such as the lands included in long-term plans of use or intentions";

- forests not available for wood supply: " forests and other forest lands where any kind of legal, economic or specific environmental limitations is intended to prevent from wood supply". It includes:

a) forests and other forest lands with legal limitations or limitations due to other political decisions, which ultimately excludes or essentially limits wood supply, in particular due to considerations of environ- 
ment or bio-diversity preservation (such as forest under protection, national parks, reservations or other protected areas);

b) forests and other forest lands where the physical productivity or the quality of wood is too low or costs for logging and transportation are too high to plan the logging.

In case of the forests available for wood supply, the forest accounting system involves the following division:

- exploited (including planted) forests that are actually managed for economic purposes (economic forests);

- unexploited (natural) forests that are beyond the active management (non-economic forests).

Forests unavailable for wood supply are grouped into:

- protective forests which function is to ensure protection of soils from erosion caused by water or wind, to prevent desertification, to reduce the risk of avalanches or rocks;
- $\quad$ protected forests, i. e. forests of special purpose, which are extremely rare by their nature or which have special cultural, religious or historical significance, including national parks, natural parks, reservations, forests intended for leisure, sports, recreation, training and scientific research, climatic or other resorts, hunting grounds, as well as the forests representing special interest for the national defense and as sources of drinking water. Because many forests fulfill the functions of protection and production at the same time, this grouping is rather ambiguous, and the distinguishing line is usually drawn for protected forests, but not for protective ones.

According to the data from the State Forest Cadastre [15], the total area of forest lands in Ukraine as of January 1, 2011, made 10378.7 thousand hectares, of which 9573.9 thousand hectares, or $92 \%$, are forest areas covered by forest plants. The latest data from the forest inventory are shown in Table 3 (compiled by data from [16]).

Table 3

The area of forest lands in Ukraine

\begin{tabular}{|l|r|r|r|}
\hline \multirow{2}{*}{ Type of forest land } & \multicolumn{2}{|c|}{$\begin{array}{c}\text { Total area of forest } \\
\text { lands, thousand } \\
\text { hectares }\end{array}$} & \multicolumn{2}{|c|}{\begin{tabular}{c}
\multicolumn{2}{|c|}{\begin{tabular}{c} 
Including the \\
\cline { 3 - 4 }
\end{tabular}} \\
\cline { 3 - 4 }
\end{tabular}} & $\begin{array}{l}\text { thousand } \\
\text { hectares }\end{array}$ & $\begin{array}{c}\text { the share in the total } \\
\text { area of forest lands, \% }\end{array}$ \\
\hline Recreation and wellness forests & 1586.1 & 1457.9 & 91.9 \\
\hline Protective forests & 3415.8 & 3117.4 & 91.2 \\
\hline $\begin{array}{l}\text { Forests of the nature protection, scientific } \\
\text { and historic-cultural purpose }\end{array}$ & 1440.0 & 1356.7 & 94.4 \\
\hline Operational forests & 3936.8 & 3641.9 & 92.5 \\
\hline Total forest area & 10378.7 & 9573.9 & 92.2 \\
\hline
\end{tabular}

Of the total forest area, 6441.9 thousand hectares, or $62 \%$, is accounted for by the forests with special mode of use (nature protection, scientific, historic and cultural purpose, recreation and wellness etc.), with the rest of 3936.8 thousand hectares, or 38\%, being operational forests.

The available data of the forest cadastre were regrouped for making international comparisons. As a result of regrouping, the forest area with special mode of use, forests available for exploitation (1718.4 thousand hectares) and the area of operated forests, including those beyond the active management (574.0 thousand hectares), are classified as the forests available for wood supply. The rest of forest areas fell into the category of forests not available for wood supply. Results of the regrouping are shown in Figure 2 (constructed by the authors by data from [16]).

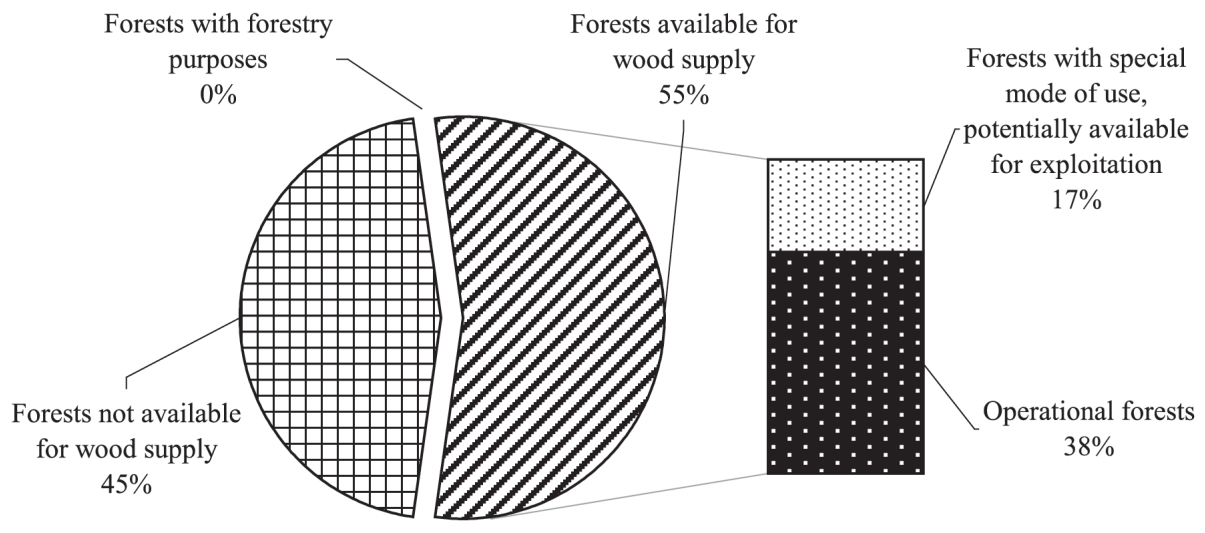

Figure 2. The distribution of forest areas in Ukraine, 2010 
Data on the forest areas in Ukraine, disseminated via official editions and websites, are different, but the tables setting correspondence between the existing definitions of the forest land area and other lands covered by forests, and the area of lands with forestry purposes by individual purpose are not available (Table 4, compiled by data from [16; 17]).

Table 4

\section{The areas of forest lands in Ukraine over time}

(thousand hectares)

\begin{tabular}{|l|r|r|r|}
\hline \multicolumn{1}{|c|}{ Type of forest land } & As of $\mathbf{0 1 . 0 1 . 2 0 1 1 ^ { \mathbf { 1 } }}$ & As of $\mathbf{0 1 . 0 1 . 2 0 1 6}{ }^{2}$ & As of $\mathbf{0 1 . 0 1 . 2 0 2 0}^{\mathbf{2}}$ \\
\hline The total area of forest lands, including: & 10378,7 & 10229,0 & 9470,2 \\
\hline - ones covered by forest plants & 9573,9 & 9698,9 & 8925,8 \\
\hline - ones not covered by forest plants & 804,8 & 216,9 & 248,2 \\
\hline - other forest lands & $\mathbf{. .}$ & 313,2 & 296,2 \\
\hline
\end{tabular}

Notes: ${ }^{1}$ Data from the State Forest Cadastre [16]. ${ }^{2}$ The State Service of Ukraine on Geodesy, Cartography and Cadastre [17].

The existing differences in the definition and the legal status of forest lands available or not available for wood supply cannot allow for a sound comparison of data and require improvements and standardization in future with respect to the definition.

The total estimated stock of forest stands as of January 1, 2011 was 2100 million $\mathrm{m} 3$, which makes $202 \mathrm{~m} 3$ per 1 hectare of the total area of forest lands or $219 \mathrm{~m} 3$ per 1 hectare of the total area of forest lands covered by forest plants [11].
The forest has been traditionally seen by Ukrainians as a source of prosperity. As of today, more than $85 \%$ of the logged wood in Ukraine is accounted for by roundwood (operational roundwood and fuel wood). Its sales in the raw form can bring stable incomes. There has been an upward tendency in the logging output since 2005. In 2019, the total logging output made 20.7 million $\mathrm{m} 3$, including 17.9 million $\mathrm{m} 3$ of roundwood, which is by $22 \%$ and $17 \%$ higher than in 2005 (Figure 3, constructed by the authors by data from [18]).

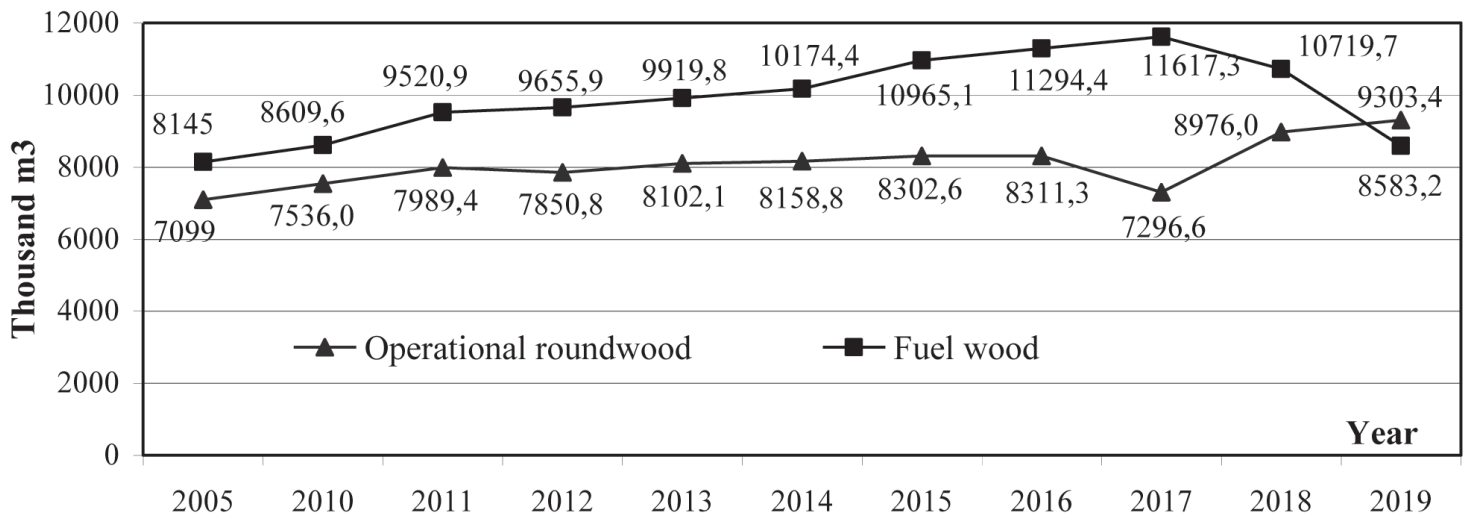

Figure 3. The logging of roundwood in Ukraine

The existing system for classification of roundwood in Ukraine does not allow for obtaining reliable data on its logging by end use category, adopted in the output statistics since long. Throughout 2019 the State Agency of Forest Resources of Ukraine was attempting to adopt the national standards of roundwood accounting, harmonized with the European standards, but because regulations of the soviet times have still been incorporated in them, the problem of breaking the roundwood by two main groups for the roundwood accounting, used for international comparisons (operational wood and fuel wood) is yet to be solved. A part of roundwood remains outside the international standards of wood accounting, and the term "fuel wood" is not covered by the national regulation.

It follows that the available data on Ukraine cannot give a comprehensive picture of the forestry. The State Agency of Forest Resources of Ukraine is the central body of the executive power responsible for the implementation of the national policy in the forestry sector, which exercises the official management in the forestry field in keeping with the enforced legal and regulatory acts. But it has to achieve its objectives by use of inconsistent or even unreliable data, which results in the destabilized situation in the sector under study and the related industries. 
The study of the forestry statistics reveals the main problems calling for improvements in methodological approaches to this statistics production:

a) a limited set of statistical data on forest resources such as the forest area or the increasing stock. In the official website of the State Statistics Service of Ukraine (www.ukrstat.gov.ua), the heading "Statistical information", there is a section of economic statistics "Agriculture, forestry and fishery", where information on the forest areas and the increasing stock is missing;

b) the unsolved problem of harmonization of the forestry statistics with international norms;

c) the unsolved methodological problems related with improvements in the statistical analysis of output and consumption of forest products on regular basis and in synchronization with the international practice;

d) the need for the constant monitoring of the information, to provide support for setting up and implementation of the national policy for the development of forestry sector.

Conclusions. So, as the significance of the forestry sector and the forestry market grows day by day, analysis of this economic sector and monitoring of its dynamics is an urgent issue. The studies of the domestic market of forest resources draws far less attention compared with the external market of forest products, which is a source of currency inflow. However, the capacity of the domestic market of forest products is an important economic indicator showing how the domestic forestry sector is developed in comparison with other countries, and the forest products in Ukraine offers can alternative option for the development of the national wood industry.

The analysis allows to outline the main areas of improvements in the forestry accounting and the propositions of the necessary steps to address the problems of statistical studies in this field. It is demonstrates that due to the institutional constraints the official statistics has a limited set of data on the domestic forest sector, forestry in particular. An important area of the improvements in the national statistical system with respect to solutions to information problems of the forestry sector is systematization of the data on its condition and performance, which have a common coverage, definitions and classifications in an integrated format. This is supposed to help in constructing the national forest accounts in a statistically consistent and integrated form in compliance with the accounting rules, principles and frameworks specified in the first international statistical standard of the environmental-economic accounting "The Central Framework of the Environmental-Economic Accounting" (2012).

\section{References}

1. European Statistics Code of Practice. Revised edition 2017. European Commission, Eurostat. ec.europa.eu. Retrieved January 13, 2020 from http://ec.europa.eu/eurostat/web/quality/european-statistics-code-ofpractice

2. Statistical requirements compendium - 2019 edition. Eurostat. Manual and Guidelines. Luxembourg: Publications Office of the European Union, 2019. ec.europa.eu. Retrieved from https://ec.europa.eu/eurostat/ en/web/products-manuals-and-guidelines/-/KS-GQ-19-012

3. Joint forest sector questionnaire (JFSQ). wrew.fao.org. Retrieved from http://www.fao.org/forestry/32128-0102d718f03c15f07600d57db79d19984.pdf

4. Eurostat: European Framework for Integrated Environmental and Economic Accounting for Forests (IEEAF), Luxembourg: Office for Official Publications of the European Communities, 2002. Retrieved from http://ec.europa.eu/eurostat/web/products-manuals-and-guidelines/-/KS-BE-02-003

5. Storozhuk, V. (2017). Ohliad stanu adaptatsii ukrainskoho lisovoho zakonodavstva do zakonodavstva yevropeiskoho soiuzu [Review of Adaptation of Ukrainian Forestry Legislation with EU Legislation]. FLEG II (ENPI East) Program. Retrieved from http://www.enpi-fleg.org/site/assets/files/2121/report_storozhuk_ assessment_approximation_ukraines_forestry_legislation_to_eu.pdf [in Ukrainian].

6. Lisovyi kodeks Ukrainy: Kodeks vid 08.07.2010 r. № 3852-XII, stanom na 03.07.2020 r. [The Forest Code of Ukraine: Code of July 08, 2010 No 3852-XII as of January 16, 2020]. zakon3.rada.gov.ua. Retrieved from http://zakon3.rada.gov.ua/laws/show/3852-12/page [in Ukrainian].

7. Hospodarskyi kodeks Ukrainy: Kodeks vid 16.01.2003 r. № 436-IV, stanom na 02.04 .2020 r. [The Business Code of Ukraine of January 16, 2003, No 436-IV as of April 02, 2020]. zakon.rada.gov.ua. Retrieved from https://zakon.rada.gov.ua/laws/show/436-15 [in Ukrainian].

8. Klasyfikatsiia instytutsiinykh sektoriv ekonomiky Ukrainy: zatverdzhena nakazom Derzhstatu vid 03.12.2014 r. № 378, stanom na 25.02.2020 r. [Classification of institutional sectors of the economy of Ukraine. Approved by the Order of the State Statistics Service of Ukraine of December 03, 2014 No 378 as of February 25, 2020].ukrstat.gov.ua. Retrieved from http://ukrstat.gov.ua/norm_doc/2020/85/85\%20(\%D0\%B7\%D1\%96\%20 $\% \mathrm{D} 0 \% \mathrm{~B} 7 \% \mathrm{D} 0 \% \mathrm{BC} \% \mathrm{D} 1 \% 96 \% \mathrm{D} 0 \% \mathrm{BD} \% \mathrm{D} 0 \% \mathrm{~B} 0 \% \mathrm{D} 0 \% \mathrm{BC} \% \mathrm{D} 0 \% \mathrm{~B} 8$ ).pdf [in Ukrainian].

9. Obsiah realizovanoi produktsii (tovariv, posluh) subiektiv hospodariuvannia za vydamy ekonomichnoi diialnosti u 2010-2018 rokakh [Volume of products (goods, services) sold by types of economic activity in 
2010-2018]. ukrstat.gov.ua. Retrieved from http://www.ukrstat.gov.ua/operativ/operativ2018/fin/pssg/ pssg_u/orpsg_ek_2010_2018_u.xlsx

10. Kapitalni investytsii za vydamy ekonomichnoi diialnosti za 2010-2019 roky [Capital investments by types of economic activity for 2010-2019]. ukrstat.gov.ua. Retrieved from http://www.ukrstat.gov.ua/ operativ/operativ2013/ibd/ibd rik/ibd u/ki rik u e bez.htm

11. Konstytutsiia Ukrainy: Zakon Ukrainy vid 28.06 .1996 r. № 254k/96-VR [Constitution of Ukraine. Law of Ukraine of June 28, 1996 № 254k/96-VR as of February 21, 2019]. zakon.rada.gov.ua. Retrieved from http://zakon3.rada.gov.ua/laws/show/254\%D0\%BA/96-\%D0\%B2\%D1\%80 [in Ukrainian].

12. Publichnyi zvit Derzhavnoho ahentstva lisovykh resursiv Ukrainy za 2019 rik [Public report of the State Agency of Forest Resources of Ukraine for 2019]. (2020). menr.gov.ua. Retrieved from https://menr.gov. ua/news/34682.html [in Ukrainian].

13. Tsentralnaia osnova Sistemy prirodno-ekonomicheskoho ucheta, 2012 god [Central basis of the System of natural and economic accounting, 2012]. (2017). New York: UN. Retrieved from https://seea.un.org/sites/ seea.un.org/files/seea_cf_final_ru_0.pdf[in Russian].

14. Pro zatverdzhennia Poriadku vedennia Derzhavnoho zemelnoho kadastru: Postanova Kabinetu Ministriv Ukrainy vid 17.10.2012 r. № 1051, stanom na 31.12.2019 r. [On approval of the Procedure for maintaining the State Land Cadastre. Resolution of the Cabinet of Ministers of Ukraine of November 17, 2012 No 1051 as of December 31, 2019). zakon.rada.gov.ua. Retrieved from https://zakon.rada.gov.ua/laws/ show/1051-2012-\%D0\%BF\#n19 [in Ukrainian].

15. Klasyfikatsiia vydiv tsilovoho pryznachennia zemel: zatverdzhena nakazom Derzhavnoho komitetu Ukrainy iz zemelnykh resursiv vid 23.07.2010 r. № 548 stanom na 11.07.2017 r. [Classification of types of land use. Approved by the Order of the State Committee of Ukraine for Land Resources of July 23, 2010 No 548 as of July 11, 2017]. zakon.rada.gov.ua. Retrieved from https://zakon.rada.gov.ua/laws/show/z1011-10\#Text [in Ukrainian].

16. Vidomosti Derzhavnoho lisovoho kadastru [Information of the State Forest Cadastre]. Official website of the Unified State Open Data Portal. data.gov.ua. Retrieved January 21, 2020 from https://data.gov.ua/ dataset/9990cd12-3f53-42ba-8d4b-c0f333ab6b62/resource/5f72c9df-5eba-4d4f-ab95-226810113756/ download/kadastrlis.xlsx [in Ukrainian].

17. Zemelnyi fond Ukrainy stanom na 1 sichnia 2016 roku ta dynamika yoho zmin u porivnyanni z danymy na 1 sichnia 2015 roku [Land Fund of Ukraine as of January 1, 2016 and the dynamics of its changes compared to data as of January 1,2015]. Official website of the State Service of Ukraine for Geodesy, Cartography and Cadastre. land.gov.ua. Retrieved January 21, 2020 from https://land.gov.ua/info/zemelnyi-fond-ukrainystanom-na-1-sichnia-2016-roku-ta-dynamika-ioho-zmin-u-porivnianni-z-danymy-na-1-sichnia-2015-roku/ [in Ukrainian].

18. Zahotivlia derevyny za vydamy lisovoi produktsii, 2010-2019 [Logging by type of forestry products, 2010-2019)]. ukrstat.gov.ua. Retrieved from http://ukrstat.gov.ua/operativ/operativ2017/sg/lis/zld/zld_u/ lisz_vyd_prod_lg_u.htm/[in Ukrainian].

\section{T. В. Кобилинська,}

\section{доктор економічних наук,}

заступник начальника,

Головне управління статистики у Житомирській області,

E-mail:TVstat@i.ua

ResearcherID: N-2678-2018,

ORCID: https://orcid.org/0000-0001-8376-9656;

Н. Ю. Гусєва,

начальник відділу,

Державна служба статистики України,

E-mail N.Guseva@ukrstat.gov.ua

ORCID: https://orcid.org/0000-0002-2655-6272

\section{Статистичне дослідження лісового господарства України}

Статтю присвячено аналізу лісового господарства України як вихідного пункту для подальшої розробки засад побудови національного лісового рахунку, який дозволяє описати взаємодію між економічною діяльністю та лісами як природним середовищем, послідовно та комплексно інтегрувати екологічні й економічні проблеми у цій сфері. Вивчено існуючі статистичні визначення, класифікації та наявну статистичну інформацію щодо лісу, проаналізовано окремі показники лісового господарства України, 
існуючі джерела даних для його аналізу, запропоновано необхідні кроки щодо подальшого застосування інструментів обліку лісів для побудови лісового рахунку.

Вказано, що лісове господарство представлено двома великими групами інституційних одиниць: фізичні особи або групи фізичних осіб у формі домашніх господарств; юридичні особи, що створені та здійснюють свою діяльність відповідно до законодавства, незалежно від того, які особи або суб'єкти можуть володіти ними чи контролювати їхню діяльність. Основними видами юридичних осіб є корпорації, некомерційні організації, органи державного управління.

Визначено , що основними джерелами даних щодо лісового фонду та лісових ресурсів країни є: статистична інформація на основі даних підприємств, отриманих за результатами державних статистичних спостережень Державної служби статистики України; адміністративні дані на основі даних підприємств, отриманих державними органами влади (Державна служба України з питань геодезії, картографії та кадастру, Державне агентство лісових ресурсів України, Міністерство захисту довкілля та природних ресурсів України, Державна митна служба, Державна податкова служба) в ході виконання іх обов'язків; 3) дані національної інвентаризації лісів, отриманих уповноваженими органами. Для України останні офіційні дані національної інвентаризації лісів сформовані станом на 01 січня 2011 року, але ці дані ще й досі належним чином не опубліковані.

Обгрунтовано, що сфера офіційної статистики охоплює обмежений набір статистичних даних щодо лісового господарства через інституційні обмеження. Досліджено динаміку та структуру площ лісових ділянок України та наведено основні проблеми, пов'язані з удосконаленням методологічних підходів до формування статистики лісового господарства. На основі проведеного аналізу визначено основні напрями удосконалення обліку в лісовому господарстві та запропоновано необхідні кроки для вирішення проблем статистичного вивчення цієї галузі.

Ключові слова: лісове господарство, лісові ділянки, ліси та інші лісові землі, деревина, діловий круглий ліс, паливна деревина, статистичне дослідження.

Bibliographic description for quoting:

Kobylynska, T. V., \& Huseva, N. Yu. (2020). A Statistical Study of the Forestry in Ukraine. Statystyka Ukrainy - Statistics of Ukraine, 2-3, 12-21 [in English]. Doi: 10.31767/su.2-3(89-90)2020.02-03.02.

Бібліографічний опис для цитування:

Кобилинська Т. В., Гусєва Н. Ю. Статистичне дослідження лісового господарства України (публікується англійською мовою). Статистика Украӥни. 2020. № 2-3. С. 12-21.

Doi: $10.31767 /$ su.2-3(89-90)2020.02-03.02. 